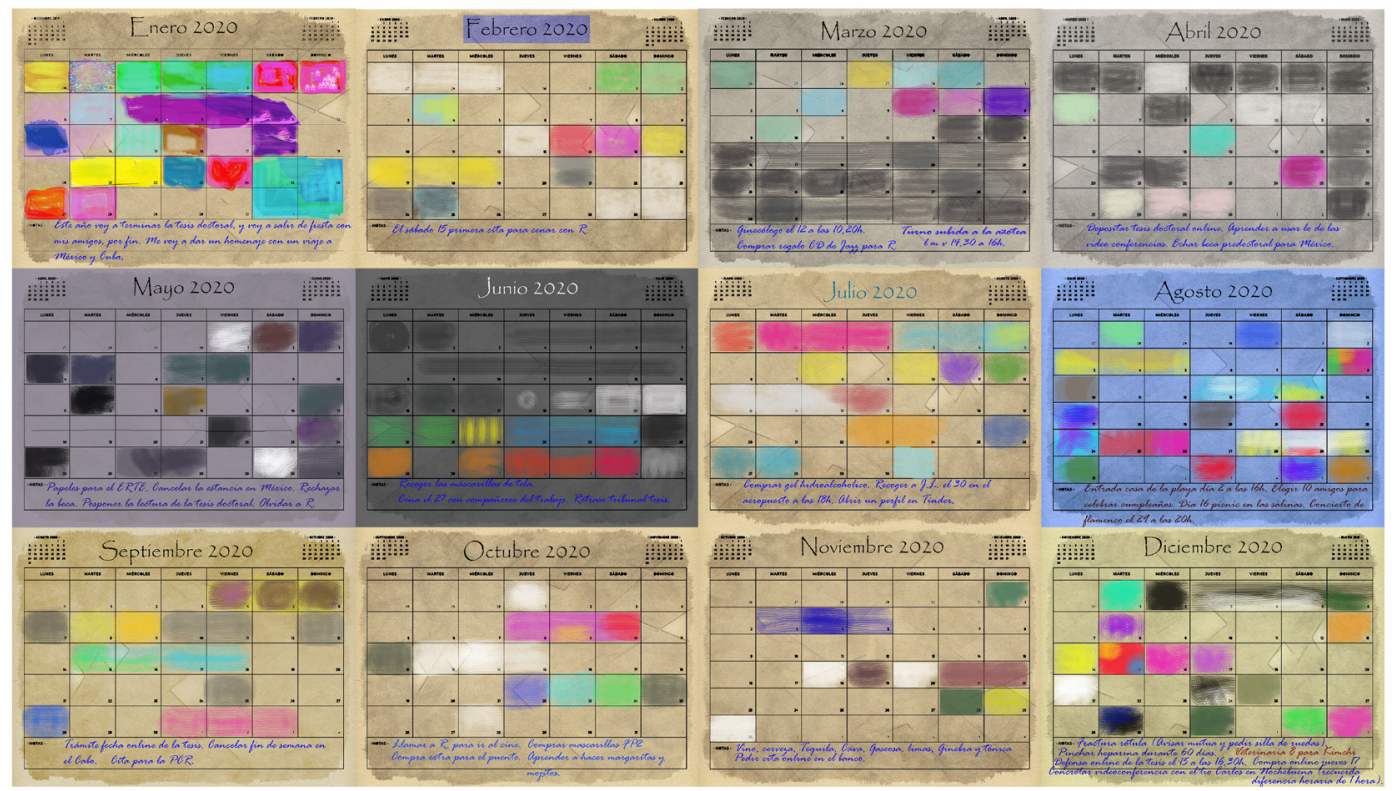

\title{
Day by day
}

\section{Reflexión}

2020, giro de $180^{\circ}$ a lo inesperado. La narrativa del color crea un pantone emocional día a día, mes a mes. Sin aclimatación el tiempo pasa lento. La soledad muerde. Se pierden las cosas más simples: abrazos y besos. La expectación crece frente al cristal líquido. Vivir es anhelar, arrancar las hojas marchitas del calendario, permitir a los tonos luminosos prosperar.

\section{Autora}

Teresa Colomina Molina. Profesora asociada Departamento de Expresión Plástica, Musical y Dinámica de la Facultad de Educación de la Universidad de Murcia.

Miembro del Grupo de Investigación E0A6-07 Prácticas artísticas activas y ciudadanía.

Arteterapia: papeles de arteterapia y educación artística para la integración social.

Monográfico: Las miradas del arte y el arteterapia en tiempos de la Covid19. ISSN-e: 1988-8309 https://dx.doi.org/10.5209/arte.75878 